\title{
Soil organic matter dynamics under different land use in grasslands in Inner Mongolia (northern China)
}

\author{
L. Zhao, W. Wu, X. Xu, and Y. Xu \\ Moe Key Laboratory for Earth Surface Processes, College of Urban and Environmental Sciences, Peking University, \\ Beijing 100871, China \\ Correspondence to: Y. Xu (yunpingxu@pku.edu.cn)
}

Received: 20 January 2014 - Published in Biogeosciences Discuss.: 11 April 2014

Revised: 19 August 2014 - Accepted: 22 August 2014 - Published: 22 September 2014

\begin{abstract}
We examined bulk soil properties and molecular biomarker distributions in surface soils from Inner Mongolian grasslands in order to understand the responses of soil organic matter to different land use. A total of 16 soils were collected from severely degraded grassland by overgrazing (DG), native grassland without apparent anthropogenic disturbance $(\mathrm{NG})$, groundwater-sustaining grassland $(\mathrm{GG})$ and restored grassland from previous potato cropland (RG). Compared to NG, soil organic carbon content was lower by $50 \%$ in DG, but higher by six-fold in GG and onefold in RG. The $\delta^{13} \mathrm{C}$ values of soil organic carbon were $24.2 \pm 0.6 \%$ in DG, $-24.9 \pm 0.6 \%$ in NG, $-25.1 \pm 0.1 \%$ o in RG and $-26.2 \pm 0.6 \%$ in GG, reflecting different degradation degrees of soil organic matter or different water use efficiencies. The soils in DG contained the lowest abundance of aliphatic lipids ( $n$-alkanes, $n$-alkanols, $n$-alkanoic acids, $\omega$-hydroxylalkanoic acids and $\alpha$-hydroxyalkanoic acids) and lignin-phenols, suggesting selective removal of these biochemically recalcitrant biomarkers with grassland degradation by microbial respiration or wind erosion. Compared to $\mathrm{NG}$, the soils in GG and RG increased $\omega$-hydroxylalkanoic acids by $60-70 \%$, a biomarker for suberin from roots, and increased $\alpha$-hydroxylalkanoic acids by $10-20 \%$, a biomarker for both cutin and suberin. Our results demonstrate that the groundwater supply and cultivation-restoration practices in Inner Mongolian grasslands not only enhance soil organic carbon sequestration, but also change the proportions of shoot- versus root-derived carbon in soils. This finding has important implications for the global carbon cycle since rootderived aliphatic carbon has a longer residence time than the aboveground tissue-derived carbon in soils.
\end{abstract}

\section{Introduction}

Soil organic carbon, representing $80 \%$ of the terrestrial active carbon pool, plays a key role in the global carbon cycle (Janzen, 2004; Schlesinger and Andrews, 2000; Watson, 2000). Recently, increased human activities such as stock grazing, cultivation, deforestation and plantation has substantially changed the carbon balance between soil and atmosphere and thereby mitigated or accelerated global climate change. Guo et al. (2007) reported that soil carbon stock up to $100 \mathrm{~cm}$ decreased by $20 \%$ after $16 \mathrm{yr}$ plantation in a native pasture of Australia, while Islam et al. (2000) found a $44 \%$ decline in soil quality in a tropical forest ecosystem in Bangladesh that was under cultivation. The change in quality and quantity of soil organic matter inevitably affects various terrestrial ecosystem functions such as the soil fertility, biological diversity and biomass productivity (Kaiser et al., 2010).

Grasslands are important ecological landscapes in China and account for $40 \%$ of the national land area (ca. $4000000 \mathrm{~km}^{2}$ ) (National Statistics Bureau of China, 2002). These grasslands are mainly distributed in the semiarid and semi-humid northern China (e.g., Inner Mongolia) and Tibetan Plateau, and are highly susceptible ecosystems for changes in climate and land use (He et al., 2008; Xiao et al., 1995; Zhou et al., 2007). Previous studies have demonstrated that improper land use can cause grassland degradation and even desertification in Inner Mongolia (e.g. Cui et al., 2005; Su et al., 2005; Wang et al., 2013; Zhao et al., 2007). However, most of these studies focused on bulk soil properties such as total organic carbon and nitrogen contents. Since SOM consists of heterogeneous mixtures of plant, microbe and animal-derived residues with 
different environmental stabilities (Baldock and Skjemstad, 2000; Kögel-Knabner, 2002), the investigation for different fractions and even molecular compositions of SOM is indispensable for understanding carbon dynamics under different land use practices (Leifeld and Kögel-Knabner, 2005).

Organic matter biomarkers are compounds specific for certain organisms (e.g., higher plants, fungi and bacteria) or tissues (e.g., leaves and root) (Kögel-Knabner, 2000; Otto et al., 2005). Free lipids from plant waxes and biopolymers such as suberin and cutin are the major sources of the aliphatic constituents of SOM, while lignin is an important contributor to aromatic components of SOM (Kögel-Knabner, 2002). Over the past decades, biomarker approaches have been successfully used to estimate SOM responses to different environmental changes such as soil warming (e.g. Feng et al., 2008), vegetation shifts (e.g. Pisani et al., 2013) and elevated atmospheric $\mathrm{CO}_{2}$ (e.g. Wiesenberg et al., 2008).

In this study, we analyzed the composition and distribution of bulk organic matter and molecular biomarkers in grassland soils from Inner Mongolia, northern China (Appendix Fig. A1). These grasslands have developed in the same climate region and have the same dominant grass species, but are subject to different levels of human disturbances. The main objectives of our study are to understand the chemical characteristics of SOM at the bulk and molecular levels in temperate grasslands in Inner Mongolia and to evaluate influences of land use practices on SOM. We also attempt to answer whether certain components of SOM such as aliphatic lipids, cutin/suberin and lignin, usually thought to be refractory components, are preferentially preserved with changes in grassland uses.

\section{Materials and methods}

\subsection{Study area and sampling}

Our study was conducted on the Keshiketengqi Grassland in the Inner Mongolia Autonomous Region (northern China), $400 \mathrm{~km}$ away from Beijing (Appendix Fig. A1). The semiarid climate has a long, cold winter (November to March) and a short summer (June to August). The mean annual temperature is $-1.5^{\circ} \mathrm{C}$ and the mean annual precipitation is $400 \mathrm{~mm}$ (Feng and Zhao, 2011; Tan et al., 2013). The soil is classified as a chestnut soil.

Four experimental fields with the size of $100 \mathrm{~m} \times 100 \mathrm{~m}$ were chosen in our study (Fig. 1), representing severely degraded grassland $\left(\mathrm{DG} ; 42^{\circ} 37^{\prime} \mathrm{N}, 117^{\circ} 05^{\prime} \mathrm{E}\right)$, native grassland $\left(\mathrm{NG} ; 42^{\circ} 35^{\prime} \mathrm{N}, 117^{\circ} 05^{\prime} \mathrm{E}\right)$, groundwater-sustaining grassland (GG; $42^{\circ} 32^{\prime} \mathrm{N}, 117^{\circ} 08^{\prime} \mathrm{E}$ ) and restored grassland from previous cropland (RG; $\left.42^{\circ} 33^{\prime} \mathrm{N}, 117^{\circ} 13^{\prime} \mathrm{E}\right)$. The DG has been subject to intense sheep and cattle grazing and trampling for over $15 \mathrm{yr}$ and its vegetation is sparse. At NG, grazing activity is rare and there was no apparent anthropogenic disturbance. Pristine grassland at the site RG was converted
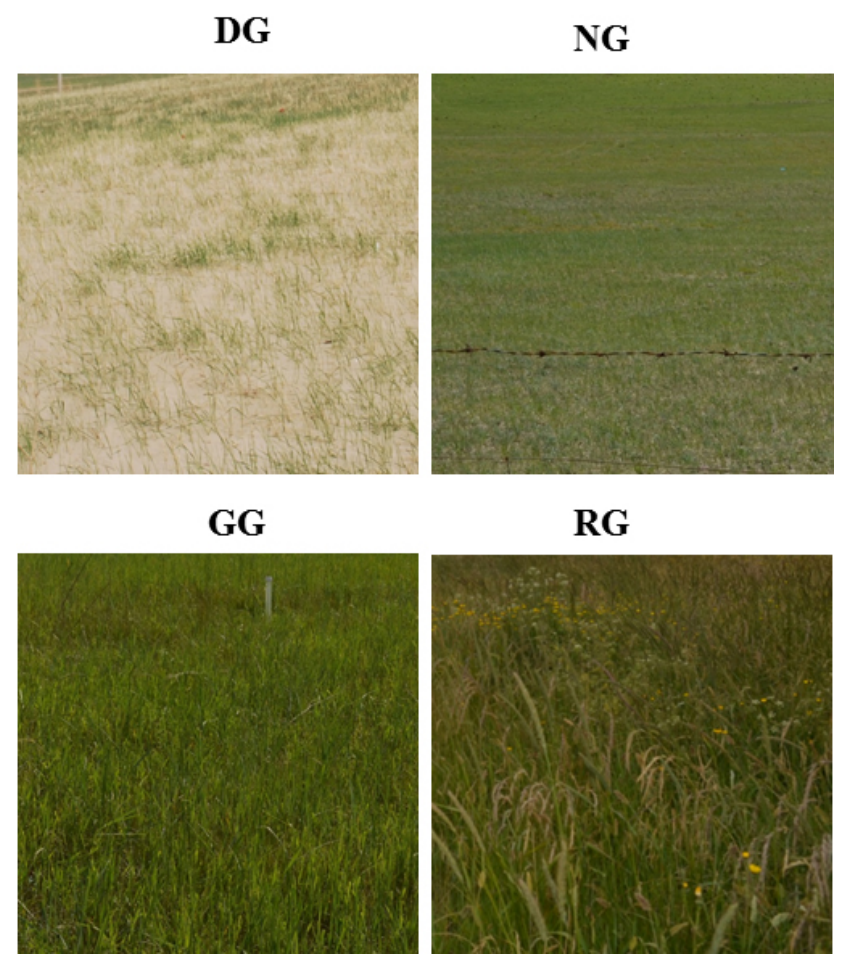

Figure 1. Pictures taking from the study sites, DG: degraded grassland by overgrazing; NG: native grassland without apparent anthropogenic disturbance; GG: groundwater-sustaining grassland; RG: restored grassland from potato cropland.

into a potato cropland in 1990, and the cultivation activities lasted until 2010. Since then, this cropland has been restored to grassland by planting indigenous grasses and banning stock grazing. The GG is in a lowland area and supplied by groundwater in summer (June to September) when rainfall is relatively high. Similar to NG, grazing activity is rare at GG.

Among the four sampling sites, the dominant vegetation species are Leymus secalinus and Agropyron mongolicum var. villosum. However, in the RG, weed annuals such as Chenopodium acuminatum and Sonchus arvensis are also present besides $L$. secalinus and A. mongolicum var. villosum in the RG. Vegetation cover varied from $38 \%$ to $84 \%$ in an increasing order of DG, NG, RG and GG. Since the NG is subject to the least anthropogenic impact and resembles the major native grasslands in the Keshiketengqi Grassland, it is regarded as the reference site. In May 2012, four soil samples $(0-10 \mathrm{~cm})$ were collected from each site by a soil auger. After sampling, the soils were freeze-dried at $-40^{\circ} \mathrm{C}$ and passed through a $2 \mathrm{~mm}$ sieve to remove large roots and coarse particles. Soil samples were stored at $-20^{\circ} \mathrm{C}$ until further analyses. 


\subsection{Grain size, elemental and stable isotope analyses}

The detailed methods for grain size measurement has been described in Sun et al. (2011). About $1.0 \mathrm{~g}$ of dried soils were reacted with excess $1 \mathrm{M}$ hydrochloric acid and then with hydrogen peroxide to remove carbonates and oxidize organic matter, respectively. After that, sodium hexametaphosphate was added, and the solutions were allowed to settle for $24 \mathrm{~h}$. After ultra-sonication for $1 \mathrm{~min}$, the grain size distributions were measured by a Mastersizer 2000 Laser Particle Size Analyzer. The scan range was from 0.02 to $2000 \mu \mathrm{m}$, and categorized into three fractions: sand $(20-2000 \mu \mathrm{m})$, silt $(2-20 \mu \mathrm{m})$ and clay $(<2 \mu \mathrm{m})$.

The procedures for elemental and stable isotopic analyses were modified from $\mathrm{Wu}$ et al. (2014). The dried soil samples were treated with $1 \mathrm{M}$ hydrochloric acid to remove inorganic carbon. The residues were analyzed by a CHNOS Element Analyzer (Elementar Germany) for total organic carbon (TOC) and total nitrogen (TN), while the $\delta^{13} \mathrm{C}$ and $\delta^{15} \mathrm{~N}$ were determined on a Flash EA1112HT coupled with MAT 253 (Thermo Fisher Scientific, Inc). The standard deviations based on the replicate analyses were $0.02 \%$ for TOC, $0.005 \%$ for TN, $0.15 \%$ ofor $\delta^{13} \mathrm{C}$ and $0.10 \%$ for $\delta^{15} \mathrm{~N}$.

\subsection{Extractions of free lipids, bound lipids and lignin-phenols}

Figure 2 shows the procedures for biomarkers analyses. About $6 \mathrm{~g}$ soil samples were mixed with $2 \mu \mathrm{g}$ squalane and extracted with ultrasonication three times, each with $15 \mathrm{~mL}$ dichloromethane: methanol $(1: 1 ; \mathrm{v} / \mathrm{v})$ for $15 \mathrm{~min}$. The combined solvent extracts were filtered through glass fiber columns, concentrated by rotary evaporation, and dried under $\mathrm{N}_{2}$ gas in $2 \mathrm{ml}$ glass vials.

Soil residues after the solvent extraction were subjected to base hydrolysis to cleave bound lipids (Otto et al., 2005). After the addition of $1 \mathrm{M}$ methanolic $\mathrm{KOH}(15 \mathrm{~mL})$ and $20 \mu \mathrm{g}$ $5 \alpha$-cholestane (internal standard), the air-dried soil residues $(\sim 3 \mathrm{~g})$ were sealed and heated at $100^{\circ} \mathrm{C}$ for $3 \mathrm{~h}$. After cooling, the suspension was acidified to $\mathrm{pH} 1$ by the addition of $6 \mathrm{M} \mathrm{HCl}$. The bound lipids were recovered from the water phase by liquid-liquid extraction with $20 \mathrm{~mL}$ ethyl acetate three times. Anhydrous $\mathrm{Na}_{2} \mathrm{SO}_{4}$ was added to remove any remaining water. The ethyl acetate extracts were concentrated by rotary evaporation, transferred to $2 \mathrm{~mL}$ glass vials and dried under nitrogen gas.

Subsamples after the base hydrolysis were oxidized with $\mathrm{CuO}$ to release lignin-derived phenols. Teflon-lined bombs were loaded with $2 \mathrm{~g}$ of dry soil, $1 \mathrm{~g} \mathrm{CuO}, 100 \mathrm{mg}$ ammonium iron (II) sulfate hexahydrate and $15 \mathrm{~mL}$ of $2 \mathrm{M} \mathrm{NaOH}$. The teflon vessels were purged with nitrogen gas for oxygen exhaustion, then sealed and heated for $2.5 \mathrm{~h}$ at $170{ }^{\circ} \mathrm{C}$. After reaction, the liquid was decanted into a $50 \mathrm{~mL}$ centrifuge tube, and the residue was washed twice, each with $10 \mathrm{~mL}$ deionized water. The combined washings were centrifuged for $10 \mathrm{~min}$ at $3000 \mathrm{rpm}$. The supernatant was transferred into another centrifuge tube, acidified to $\mathrm{pH} 1$ by the addition of $6 \mathrm{M} \mathrm{HCl}$ and kept for $1 \mathrm{~h}$ at room temperature in the dark to prevent reactions of cinnamic acids. After centrifugation for $10 \mathrm{~min}$ at $3000 \mathrm{rpm}$ again, the supernatant was transferred to a separation funnel and liquid-liquid extracted three times, each with $20 \mathrm{~mL}$ ethyl acetate. Anhydrous $\mathrm{Na}_{2} \mathrm{SO}_{4}$ was added to remove water. The ethyl acetate extracts were concentrated by rotary evaporation, transferred to $2 \mathrm{~mL}$ glass vials and dried under nitrogen gas.

\subsection{Derivatization of extracts and instrumental analyses}

The base hydrolysis extracts were first methylated by a reaction of $14 \% \mathrm{BF} 3: \mathrm{MeOH}$ for $90 \mathrm{~min}$ at $70^{\circ} \mathrm{C}$. The bound lipids were obtained by liquid-liquid extraction with $2 \mathrm{~mL}$ hexane $(3 \times)$, and dried under an $\mathrm{N}_{2}$ stream. After that, all biomarkers from solvent extracts, base hydrolysis and $\mathrm{CuO}$ oxidation were trimethylsilyl (TMS) derivatized by reaction with $50 \mu \mathrm{L} N, O$-bis-(trimethylsilyl) trifluoroacetamide (BSTFA) and $10 \mu \mathrm{L}$ pyridine for $2 \mathrm{~h}$ at $60^{\circ} \mathrm{C}$. After cooling, DCM was added to dilute to $1 \mathrm{~mL}$.

The biomarkers were identified by gas chromatographymass spectrometry (GC-MS). This instrument was composed of an Agilent 7890A GC coupled to an Agilent 5973N quadruple mass selective detector. The biomarkers were separated by a DB-5 capillary column $(30 \mathrm{~m} ; 0.25 \mathrm{~mm}$ i.d.; $0.25 \mu \mathrm{m}$ film thickness). A $1 \mu \mathrm{L}$ of samples was injected in the splitless mode under a constant flow $\left(1.0 \mathrm{~mL} \mathrm{~min}^{-1}\right)$. The injector temperature was $300^{\circ} \mathrm{C}$. High pure helium (>99.999\%) was used as carrier gas. The mass spectrometer was operated in the electron impact mode $(70 \mathrm{eV})$. The mass scan range was 50 to $550 \mathrm{Da}$.

An Agilent 7890A GC coupled to a flame ionization detector (FID) was used for quantification of biomarkers. The separation was achieved on an HP 5 capillary column $(30 \mathrm{~m}$; $0.32 \mathrm{~mm}$ i.d.; $0.25 \mu \mathrm{m}$ film thickness). The injector temperature was $300{ }^{\circ} \mathrm{C}$. A $1 \mu \mathrm{L}$ volume of sample was injected in splitless mode under a constant flow $\left(1.5 \mathrm{~mL} \mathrm{~min}^{-1}\right)$. Helium (purity $>99.999 \%$ ) was the carrier gas.

Oven programs for GC-MS and GC-FID were set as follows: temperature was held at $60^{\circ} \mathrm{C}$ for $1 \mathrm{~min}$, increased to $300^{\circ} \mathrm{C}$ at a rate of $6^{\circ} \mathrm{C} \min ^{-1}$ with a final isothermal hold at $300^{\circ} \mathrm{C}$ for $20 \mathrm{~min}$. For solvent extracts and base hydrolysis, the biomarkers were quantified by comprising the peak areas of biomarkers to an internal standard (squalane for free lipids and $5 \alpha$-cholestane for bound lipids), while the amounts of lignin phenols were determined by the calibration curves of eight lignin-phenol standards. 


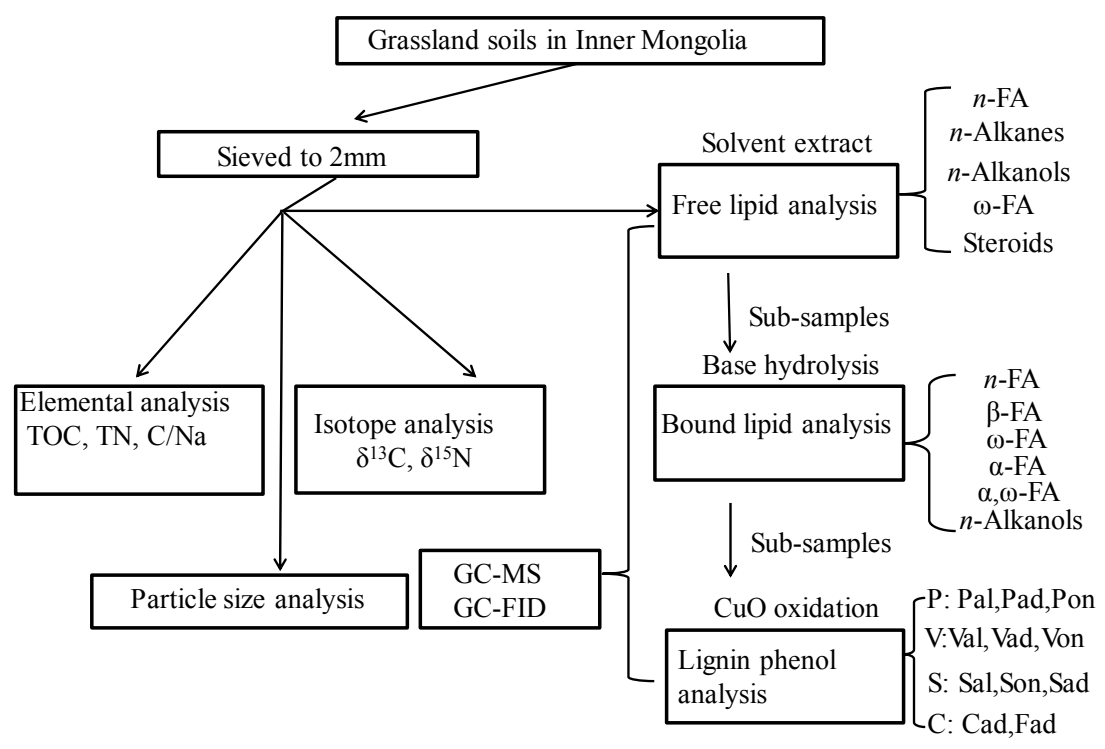

Figure 2. Flow chart of bulk parameters and molecular biomarker analyses for grassland soils, Inner Mongolia. FA = fatty acids.

\section{Statistical analysis}

The program package SPSS 18.0 (Illinois, USA) was used for statistical analyses. One-way ANOVA analysis was conducted to examine the differences in bulk properties and molecular biomarkers among soils from different grasslands. All analyses were performed with a significance level of $P<0.05$.

\section{Results}

\subsection{Elemental and isotopic compositions}

Table 1 shows the grain size distributions, elemental and isotopic compositions of grassland soils. All soils were dominated by sand (64.4 to $87.3 \%$ ), while clay fractions accounted for only 1.7 to $6.4 \%$ in an increasing order of DG, NG, GG and RG. The TOC content ranged from $3.2 \pm 0.2 \mathrm{~g} \mathrm{~kg}^{-1}$ (DG) to $46.6 \pm 16.7 \mathrm{~g} \mathrm{~kg}^{-1}$ (GG), while the TN content gradually increased from $0.32 \pm 0.15 \mathrm{~g} \mathrm{~kg}^{-1}$ (DG) to $3.9 \pm 1.5 \mathrm{~g} \mathrm{~kg}^{-1}(\mathrm{GG})$. The values of $\delta^{13} \mathrm{C}$ and $\delta^{15} \mathrm{~N}$ varied from $-24.2 \pm 0.6 \%$ (DG) to $-26.2 \pm 0.6 \%$ (GG) and $0.36 \pm 0.3 \%$ o (DG) to $4.8 \pm 1.6 \%$ (GG), respectively. The $\mathrm{C} / \mathrm{N}$ ratio increased from 9.9 to 12.5 in an order of DG, NG, GG and RG. A significant linear correlation was observed between the $\delta^{13} \mathrm{C}$ and $\mathrm{C} / \mathrm{N}$ ratio $(r=-0.667, n=16$, $p<0.01$ ), suggesting that both parameters are controlled by the same factors such as the source and degradation stage of SOM.

\subsubsection{Compositions and distributions of solvent extracts}

The major components of the solvent extracts were $n$ alkanoic acids, $n$-alkanols, $\omega$-hydroxyalkanoic acids, $n$ - alkanes, steroids and sugars (Fig. A2). The concentrations of each type of biomarkers were summarized in Fig. 3. Long-chain $\left(>\mathrm{C}_{20}\right)$ aliphatic lipids including $n$-alkanes, $n$ alkanols and $n$-alkanoic acid are derived from epicuticular waxes of vascular plants, while short-chain $\left(<\mathrm{C}_{20}\right)$ aliphatic lipids are of a microbial origin (Otto et al., 2005; Simoneit, 2005). The soils from NG contained the highest concentrations of free aliphatic lipids $\left(3.53 \pm 1.18 \mathrm{mg} \mathrm{g}^{-1} \mathrm{OC}\right)$, followed by those from DG $\left(2.23 \pm 1.03 \mathrm{mg} \mathrm{g}^{-1} \mathrm{OC}\right), \mathrm{RG}$ $\left(1.36 \pm 0.73 \mathrm{mg} \mathrm{g}^{-1} \mathrm{OC}\right)$ and $\mathrm{GG}\left(1.20 \pm 0.65 \mathrm{mg} \mathrm{g}^{-1} \mathrm{OC}\right)$. Since the biomarker abundances have been normalized to organic carbon, the lowest concentrations of free aliphatic lipids at GG and RG were attributed to a dilution effect of their relatively high TOC contents. The homologues of $n$-alkanoic acids $\left(\mathrm{C}_{14}\right.$ to $\left.\mathrm{C}_{32}\right)$ were detected at the total concentrations of $1.20 \pm 0.39 \mathrm{mg} \mathrm{g}^{-1} \mathrm{OC}$ in NG, $0.54 \pm 0.24 \mathrm{mg} \mathrm{g}^{-1} \mathrm{OC}$ in DG, $0.40 \pm 0.37 \mathrm{mg} \mathrm{g}^{-1} \mathrm{OC}$ in $\mathrm{RG}$ and $0.38 \pm 0.23 \mathrm{mg} \mathrm{g}^{-1} \mathrm{OC}$ in GG. These $n$-alkanoic acids were characterized by the strong even-over-odd carbon numbered predominance and the $\mathrm{C}_{\max }$ at $\mathrm{C}_{16}$ and $\mathrm{C}_{24}$, suggesting a mixed input of soil microbes and vascular plants. Besides saturated acids, mono- and di-unsaturated $\mathrm{C}_{16}$ and $\mathrm{C}_{18}$ nalkanoic acids were also detected at the concentrations lower than $0.25 \mathrm{mg} \mathrm{g}^{-1} \mathrm{OC}$. These short-chain unsaturated alkanoic acids are mainly biosynthesized by bacteria and fungi.

The homologous $n$-alkanes $\left(\mathrm{C}_{22}\right.$ to $\left.\mathrm{C}_{33}\right)$ displayed a strong odd-over-even predominance and the maximum abundance $\left(\mathrm{C}_{\max }\right)$ at $\mathrm{C}_{29}$. The soils in NG were composed of the highest abundant $n$-alkanes $\left(0.33 \pm 0.08 \mathrm{mg} \mathrm{g}^{-1} \mathrm{OC}\right)$, followed by soils in DG $\left(0.32 \pm 0.12 \mathrm{mg} \mathrm{g}^{-1} \mathrm{OC}\right)$, RG $\left(0.31 \pm 0.20 \mathrm{mg} \mathrm{g}^{-1} \mathrm{OC}\right)$ and $\mathrm{GG}\left(0.06 \pm 0.02 \mathrm{mg} \mathrm{g}^{-1} \mathrm{OC}\right)$. Series of $n$-alkanols $\left(\mathrm{C}_{18}-\mathrm{C}_{32}\right)$ presented a strong even-over-odd predominance, with a concentration of 
Table 1. Grain size distribution, total organic carbon (TOC), total nitrogen (TN), $\delta^{13} \mathrm{C}$ and $\delta^{15} \mathrm{~N}$ values of soils from degraded grassland (DG), native grassland (NG), GG groundwater-sustaining grassland (GG) and restored grassland (RG) in Inner Mongolia. Four soil samples were analyzed for each type of grassland.

\begin{tabular}{llllllll}
\hline & Clay $(\%)$ & Silt $(\%)$ & Sand $(\%)$ & $\begin{array}{l}\text { TOC } \\
\left(\mathrm{g} \mathrm{kg}^{-1}\right)\end{array}$ & $\begin{array}{l}\mathrm{TN} \\
\left(\mathrm{g} \mathrm{kg}^{-1}\right)\end{array}$ & $\delta^{13} \mathrm{C}(\% o)$ & $\delta^{15} \mathrm{~N}(\% o)$ \\
\hline DG & $1.7 \pm 0.9^{2} \mathrm{c}$ & $11.0 \pm .8 \mathrm{~b}$ & $87.3 \pm 5.6 \mathrm{a}$ & $3.2 \pm 0.2 \mathrm{~d}$ & $0.32 \pm 0.15 \mathrm{~d}$ & $-24.2 \pm 0.6 \mathrm{a}$ & $4.14 \pm 0.50 \mathrm{a}$ \\
NG & $4.6 \pm 1.6 \mathrm{~b}$ & $21.6 \pm 7.8 \mathrm{a}$ & $73.8 \pm 9.4 \mathrm{~b}$ & $6.6 \pm 0.25 \mathrm{c}$ & $0.65 \pm 0.25 \mathrm{c}$ & $-24.9 \pm 0.6 \mathrm{a}$ & $3.31 \pm 0.45 \mathrm{~b}$ \\
GG & $5.3 \pm 0.7 \mathrm{ab}$ & $26.0 \pm 4.5 \mathrm{a}$ & $68.8 \pm 5.1 \mathrm{~b}$ & $46.6 \pm 16.7 \mathrm{a}$ & $3.9 \pm 1.5 \mathrm{a}$ & $-26.2 \pm 0.6 \mathrm{~b}$ & $2.77 \pm 0.27 \mathrm{~b}$ \\
RG & $6.4 \pm 1.0 \mathrm{a}$ & $29.2 \pm 5.6 \mathrm{a}$ & $64.4 \pm 6.5 \mathrm{~b}$ & $15.9 \pm 3.4 \mathrm{~b}$ & $1.3 \pm 0.03 \mathrm{~b}$ & $-25.1 \pm 0.1 \mathrm{a}$ & $4.51 \pm 0.37 \mathrm{a}$ \\
\hline
\end{tabular}

${ }^{1}$ Clay $(<2 \mu \mathrm{m})$, silt $(2-200 \mu \mathrm{m})$ and sand $(200-2000 \mu \mathrm{m})$.

${ }^{2}$ All values are expressed as means of four replicates \pm standard errors

* Different letters $(\mathrm{a}, \mathrm{b}, \mathrm{c}, \mathrm{d})$ in column indicate significant difference $(P<0.05)$

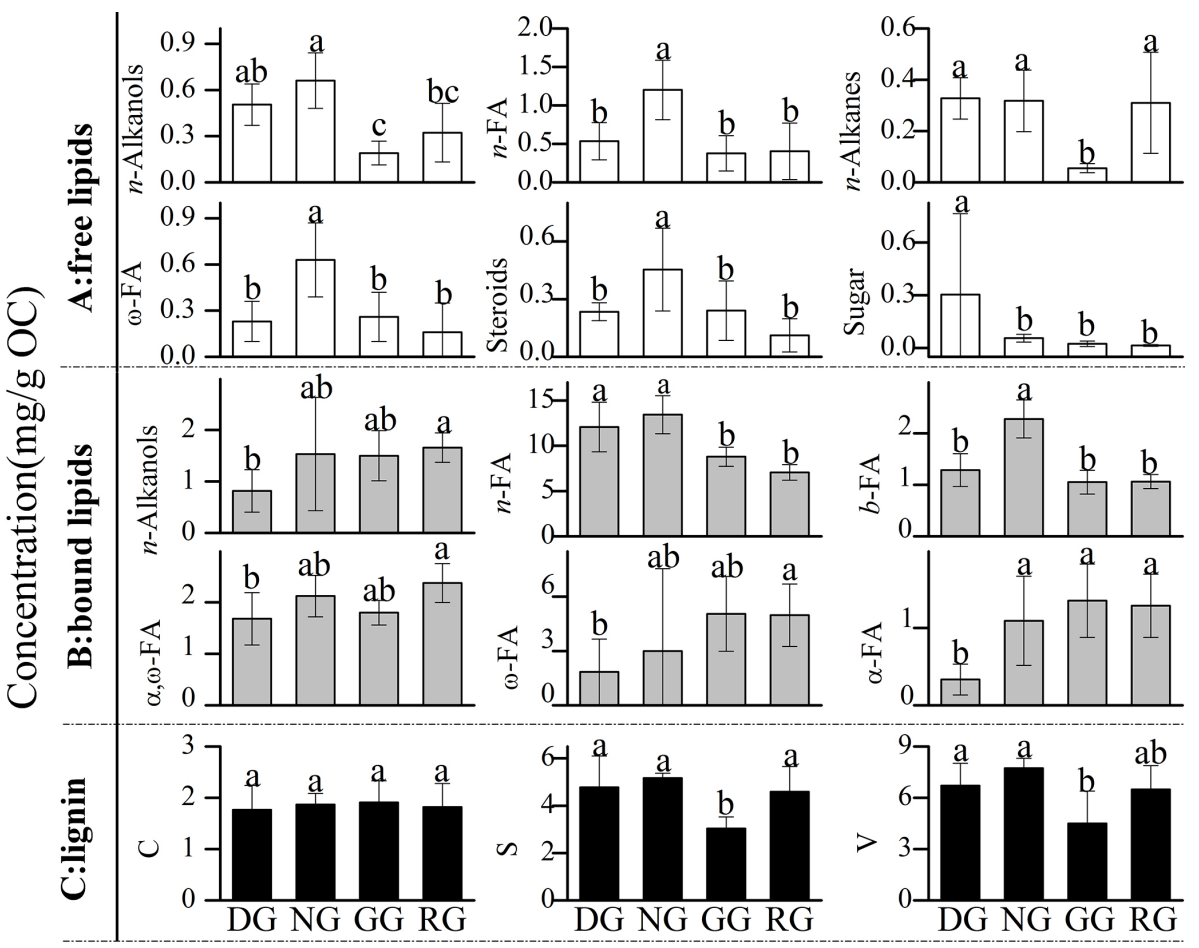

Figure 3. Concentrations ( $\mathrm{mg} \mathrm{g}^{-1} \mathrm{OC}$ ) of free lipids, bound lipids and lignin-phenols in the grassland soils in Inner Mongolia. DG: degraded grassland by overgrazing; NG: native grassland without apparent anthropogenic disturbance; GG: groundwater-sustaining grassland; RG: restored grassland from previous cultivated land. The values presented are the means of four replicates \pm standard errors. Different letters (a, b, c, d) above each column bar indicate significant difference $(P<0.05)$.

$0.66 \pm 0.18 \mathrm{mg} \mathrm{g}^{-1} \mathrm{OC}(\mathrm{NG}), 0.50 \pm 0.13 \mathrm{mg} \mathrm{g}^{-1} \mathrm{OC}(\mathrm{DG})$, $0.32 \pm 0.19 \mathrm{mg} \mathrm{g}^{-1} \mathrm{OC} \quad(\mathrm{RG})$ and $0.19 \pm 0.08 \mathrm{mg} \mathrm{g}^{-1} \mathrm{OC}$ (GG). Five $\omega$-hydroxyalkanoic acids $\left(\mathrm{C}_{22}\right.$ to $\left.\mathrm{C}_{28}\right)$ were detected with a concentration of $0.63 \pm 0.24 \mathrm{mg} \mathrm{g}^{-1} \mathrm{OC}$ in $\mathrm{NG}, 0.26 \pm 0.16 \mathrm{mg} \mathrm{g}^{-1} \mathrm{OC}$ in GG, $0.23 \pm 0.13 \mathrm{mg} \mathrm{g}^{-1} \mathrm{OC}$ in DG and $0.16 \pm 0.19 \mathrm{mg} \mathrm{g}^{-1} \mathrm{OC}$ in RG. Steroids, including $\beta$-sitosterol, cholesterol, campesterol and stigmasterol, were only minor components $\left(<0.21 \pm 0.14 \mathrm{mg} \mathrm{g}^{-1} \mathrm{OC}\right)$. Cholesterol is of a mixture origin from plants, fungi and animals, while other steroids are predominantly derived from higher plants (Otto et al., 2005 and references therein).
Several free carbohydrates, including glucose, mannose and sucrose, were detected and their abundance was lower than $0.30 \pm 0.46 \mathrm{mg} \mathrm{g}^{-1} \mathrm{OC}$.

\subsection{Compositions and distributions of bound lipids}

Homologous aliphatic lipids (alkanoic acids, alkanols, alkanedioic acids, hydroxyalkanoic acids) and steroids were major constituents of the base hydrolysis products (Fig. 3 and Fig. A2). These bound aliphatic lipids are mainly derived from the biomacromolecular suberin and cutin of vascular plants (Kögel-Knabner, 2002; Nierop et al., 2003; Otto et 
al., 2005). Among them, $n$-alkanoic acids ranging from $\mathrm{C}_{14}$ to $\mathrm{C}_{32}$ (with $\mathrm{C}_{\max }$ at $\mathrm{C}_{16}$, mono- and di-unsaturated $n-\mathrm{C}_{16}$ and $n-\mathrm{C}_{18}$ ) acids are dominant with the total concentrations of $7.1 \pm 0.9 \mathrm{mg} \mathrm{g}^{-1} \mathrm{OC}$ (RG) to $13.4 \pm 2.1 \mathrm{mg} \mathrm{g}^{-1} \mathrm{OC}$ (NG). Branched alkanoic acids including iso- $\mathrm{C}_{14}$, iso- $\mathrm{C}_{15}$, iso- $\mathrm{C}_{16}$, iso- $\mathrm{C}_{17}$ and iso- $\mathrm{C}_{18}$ were also detected and varied in concentrations from $1.05 \pm 0.23 \mathrm{mg} \mathrm{g}^{-1} \mathrm{OC}$ (GG) to $2.28 \pm 0.37 \mathrm{mg} \mathrm{g}^{-1} \mathrm{OC}(\mathrm{NG})$. Branched alkanoic acids, along with short-chain $n$-alkanoic acids $\left(<\mathrm{C}_{20}\right)$ reflect inputs from soil microbes, since these compounds are usually not biosynthesized by higher plants (e.g., Otto et al., 2005). After $n$-alkanoic acids, $\omega$-hydroxyalkanoic acids from $\mathrm{C}_{16}$ to $\mathrm{C}_{26}$ and with $\mathrm{C}_{\max }$ at $\mathrm{C}_{20}$ or $\mathrm{C}_{22}$ were the secondarily most abundant type of biomarkers, with a concentration of $1.85 \pm 1.80 \mathrm{mg} \mathrm{g}^{-1} \mathrm{OC}$ (DG) to $5.05 \pm 2.07 \mathrm{mg} \mathrm{g}^{-1} \mathrm{OC}$ (GG). The $\alpha, \omega$-alkanedioic acids, including $\mathrm{C}_{8}, \mathrm{C}_{9}, \mathrm{C}_{10}$, $\mathrm{C}_{11}$ and long-chain even numbered acids from $\mathrm{C}_{16}$ to $\mathrm{C}_{28}$, varied from $1.68 \pm 0.51$ to $2.38 \pm 0.38 \mathrm{mg} \mathrm{g}^{-1} \mathrm{OC}$. The homologues of $\mathrm{C}_{16}-\mathrm{C}_{28} \quad \alpha$-hydroxyalkanoic acids and $n$ alkanols $\left(\mathrm{C}_{16}-\mathrm{C}_{30}\right)$ were minor components of bound lipids $\left(<2.0 \mathrm{mg} \mathrm{g}^{-1} \mathrm{OC}\right)$.

\subsection{Lignin degradation products after $\mathrm{CuO}$ oxidation}

Eight lignin-derived phenols were identified in the $\mathrm{CuO}$ oxidation extracts of the soil residues after base hydrolysis, including three vanillyl (V; vanillin, acetovanillone, vanillic acid), three syringyl (S; syringaldehyde, acetosyringone, syringic acid) and two cinnamyl $(\mathrm{C} ; p$-coumaric acid and ferulic acid) groups (Fig. A2). The concentrations of total lignin phenols $(\mathrm{V}+\mathrm{S}+\mathrm{C})$ were $9.5 \pm 2.1 \mathrm{mg} \mathrm{g}^{-1} \mathrm{OC}$ in GG, $12.9 \pm 2.7 \mathrm{mg} \mathrm{g}^{-1} \mathrm{OC}$ in $\mathrm{RG}, 13.3 \pm 5.1 \mathrm{mg} \mathrm{g}^{-1} \mathrm{OC}$ in $\mathrm{NG}$, and $22.2 \pm 7.7 \mathrm{mg} \mathrm{g}^{-1} \mathrm{OC}$ in DG (Fig. 3). The ratios of $\mathrm{C}: \mathrm{V}$ and $\mathrm{S}: \mathrm{V}$ were calculated to estimate the source of lignins, since S-unit is absent in gymnosperms, while Cunit is specific for non-woody tissues (Hedges and Mann, 1979). The $C: V$ and $S: V$ ratios change with the degradation stages of lignins because the chemical stability of ligninphenols is in an order of $\mathrm{V}>\mathrm{S}>\mathrm{C}$ (Hedges et al., 1988; Otto et al., 2005). Here, we calculated the abundant ratios of acids over corresponding aldehydes $(\mathrm{Ad} / \mathrm{Al})$ of lignin phenols. With the lignin degradation by white-rot and brown-rot fungi, the aldehydes are oxidized into corresponding acids, and thus the Ad/Al values are indicative of the degradation stage of organic matter (e.g. Hedges et al., 1988). Nonwoody tissues such as grasses and leaves have been reported to have higher $\mathrm{Ad} / \mathrm{Al}$ values $(0.2-1.6)$ than angiosperm and conifer wood (0.1-0.5) (Hedges et al., 1988; Otto and Simpson, 2006a). In our study, all soils showed similar S / V values ranging from 0.67 to 0.79 (Table 2), in agreement with the same vegetation cover in all grasslands. Significant differences of $(\mathrm{Ad} / \mathrm{Al})_{V}(0.35-1.47$ in an increasing order of $\mathrm{NG}<\mathrm{RG}<\mathrm{DG}<\mathrm{GG})$ and $(\mathrm{Ad} / \mathrm{Al})_{S}(0.58--2.26$ in an increasing order of $\mathrm{NG}<\mathrm{DG}<\mathrm{RG}<\mathrm{GG}$ ) were observed (Table 2), reflecting different degradation degrees of lignin.
Table 2. Source and degradation parameters of lignin phenols in grassland soils in Inner Mongolia. DG: degraded grassland by overgrazing; NG: native grassland without apparent anthropogenic disturbance; GG: groundwater-sustaining grassland; RG: restored grassland from previous cultivated land. Four soil samples were analyzed for each type grassland.

\begin{tabular}{lllll}
\hline Fields & $\mathrm{C} / \mathrm{V}$ & $\mathrm{S} / \mathrm{V}$ & $(\mathrm{Ad} / \mathrm{Al})_{V}$ & $(\mathrm{Ad} / \mathrm{Al})_{S}$ \\
\hline DG & $0.26 \pm 0.04 \mathrm{~b}$ & $0.75 \pm 0.29 \mathrm{a}$ & $1.43 \pm 0.55 \mathrm{a}$ & $0.59 \pm 0.49 \mathrm{c}$ \\
NG & $0.24 \pm 0.02 \mathrm{~b}$ & $0.67 \pm 0.05 \mathrm{a}$ & $0.58 \pm 0.07 \mathrm{~b}$ & $0.35 \pm 0.03 \mathrm{c}$ \\
GG & $0.47 \pm 0.16 \mathrm{a}$ & $0.79 \pm 0.4 \mathrm{a}$ & $2.26 \pm 0.99 \mathrm{a}$ & $1.47 \pm 0.32 \mathrm{a}$ \\
RG & $0.28 \pm 0.04 \mathrm{~b}$ & $0.71 \pm 0.09 \mathrm{a}$ & $0.98 \pm 0.13 \mathrm{a}$ & $0.76 \pm 0.09 \mathrm{~b}$ \\
\hline
\end{tabular}

* Values are expressed as mean $\pm \mathrm{SD}$ of four determinations. Different letters (a, b, c, d) indicate significant difference $(P<0.05)$.

\section{Discussion}

\subsection{Changes in bulk soil organic matter properties under different land use}

Over recent decades, land uses such as cultivation and grazing have caused considerable reduction of vegetation cover, destruction of topsoil structure and compaction of soil in Inner Mongolian grasslands in northern China (Cui et al., 2005; Wang et al., 2013). Consequently, degradation and even desertification have become a common phenomenon in Inner Mongolian grasslands (Su et al., 2005). A series of strategies including grazing exclusion, planting indigenous plants, and returning farmlands to grasslands have been implemented to protect the regional environments (Jiang et al., 2006). However, the effects of these strategies on the quality and quantity of SOM are not fully understood.

In this study, a strong correlation was observed between TOC and TN $(r=0.999, n=16, p<0.01)$, suggesting that nitrogen is primarily associated with SOM. There are significant differences in soil organic carbon and nitrogen contents among four sampling sites. A six-fold increase of soil organic carbon content in GG compared to NG suggests that an enhanced water supply can be an effective strategy for the sequestration of organic carbon in soils. This is not surprising because the Inner Mongolian grasslands are mainly distributed in semiarid and arid regions where water is one of the limiting factors for vegetation growth. In addition, increasing water content in soils can reduce oxygen diffusion rate and thereby decrease the decomposition of SOM. Soil organic carbon and nitrogen contents in RG is about onefold higher than in NG, which is likely attributed to the fact that (1) continuous potato cultivation for two decades (19902010) resulted in the accumulation of more organic carbon and nitrogen in soils; and/or (2) banning grazing for 2 years (2010-2012) benefitted organic carbon inputs and preservation in grassland soils. Among the four field sites, RG is characterized by the highest $\delta^{15} \mathrm{~N}$ values $(4.5 \pm 0.4 \%$; Table 1$)$, suggesting an important effect of previous cultivation activities. In Inner Mongolia, stock manures were commonly used 
as fertilizers, which has remarkably higher $\delta^{15} \mathrm{~N}$ values $(10$ to $20 \%$ ) than plants (close to 0\%o) (Bateman et al., 2005; Kohl et al., 1973).

In contrast to GG and RG, about a $50 \%$ reduction of soil organic carbon and nitrogen contents was observed for DG, suggesting that overgrazing caused sparse vegetation cover and thereby decreased organic matter inputs to soils. In addition, with the lack of vegetation, the strong northwestern wind during the Asian winter monsoon can accelerate soil erosion, particularly for fine particles (e.g., Cui et al., 2005; Su et al., 2005; Zhao et al., 2007). This wind erosion effect is reflected by a significantly lower clay fraction in DG $(1.7 \pm 0.9 \%)$ than NG (4.6 $\pm 1.6 \%$; Table 1$)$. Since SOM is enriched in fine particles (Anderson et al., 1981; Nichols, 1984), the loss of clay fractions further reduced SOM levels in DG.

The $\delta^{13} \mathrm{C}$ value is a useful tracer for organic matter sources (e.g., C3 and C4 plants) degradation stage (Farquhar et al., 1989; O'Leary, 1981) and water use efficiency (Wang et al., 2008). In our study, the dominant grass species, Leymus chinensis and Stipa grandis, are C3 plants, and thus the effect of $\mathrm{C} 3 / \mathrm{C} 4$ plant shift on the $\delta^{13} \mathrm{C}$ value was not considered. The degradation of soil organic matter can cause $\delta^{13} \mathrm{C}$ values to positively shift by several per mil due to the preferential utilization of light carbon isotope by soil microbes (Feng, 2002; Natelhoffer and Fry, 1988), while the $\delta^{13} \mathrm{C}$ values of $\mathrm{C} 3$ plant leaves decrease with increasing rainfall by a coefficient of ca. $-0.4 \% / 100 \mathrm{~mm}$ (Wang et al., 2008). Among four sampling sites, GG presented a significant difference in $\delta^{13} \mathrm{C}$ values of SOM $(-26.2 \pm 0.6 \%$ o $)$ compared to the other three sites ( -24.2 to $-25.1 \%$; Table 1$)$, reflecting the largest inputs of fresh, undegraded organic matter due to high primary productivity or the change of water use efficiency with groundwater supply.

\subsection{Molecular compositions of SOM in different grasslands}

Compared to NG, DG contained significantly lower concentrations of total free lipids, cutin/suberin-monomers and lignin-phenols (Fig. 3). Such differences can be explained by two mechanisms. First, aliphatic and lignin biomarkers are preferentially degraded constituents of bulk SOM. This hypothesis is consistent with previous results that the turnover of lignin is faster than bulk SOM (e.g., Dignac et al., 2005; Gleixner et al., 2002; Thevenot et al., 2010) as well as soil fungi and bacteria-synthesized compounds (e.g., Amelung et al., 2008). In contrast, carbohydrates such as glucose, mannose and sucrose, usually thought to be biochemically labile compounds (Lorenz et al., 2007; Schmidt et al., 2011), were in significantly higher abundance in DG $\left(304.0 \pm 460.5 \mu \mathrm{g} \mathrm{g}^{-1} \mathrm{OC}\right)$ than $\mathrm{NG}\left(56.1 \pm 21.9 \mu \mathrm{g} \mathrm{g}^{-1} \mathrm{OC}\right.$; Fig. 3). The enrichment of free carbohydrates in DG is indicative of higher proportions of microbial carbon in degraded soils, supported by their heaviest $\delta^{13} \mathrm{C}$ values of SOM
Table 3. Enrichment factors $(\mathrm{Ec})$ of biomarkers in the grassland soils (Inner Mongolia) under different land use practices. DG: degraded grassland by overgrazing; NG: native grassland without apparent anthropogenic disturbance; GG: groundwater-sustaining grassland; RG: restored grassland from previous cultivated land. $\mathrm{FA}=$ fatty acids. Four soil samples were analyzed for each type of grassland.

\begin{tabular}{lllll}
\hline Field & Free lipids & $\omega-\mathrm{FA}$ & $\alpha-\mathrm{FA}$ & Lignin \\
\hline DG & $0.63 \pm 0.29 \mathrm{~b}$ & $0.62 \pm 0.60 \mathrm{c}$ & $0.31 \pm 0.18 \mathrm{~b}$ & $0.90 \pm 0.03 \mathrm{~b}$ \\
NG & $1.00 \pm 0.33 \mathrm{a}$ & $1.00 \pm 1.52 \mathrm{~b}$ & $1.00 \pm 0.53 \mathrm{a}$ & $1.00 \pm 0.06 \mathrm{a}$ \\
GG & $0.34 \pm 0.18 \mathrm{c}$ & $1.69 \pm 0.69 \mathrm{a}$ & $1.24 \pm 0.43 \mathrm{a}$ & $0.64 \pm 0.14 \mathrm{c}$ \\
RG & $0.39 \pm 0.21 \mathrm{c}$ & $1.66 \pm 0.58 \mathrm{a}$ & $1.18 \pm 0.37 \mathrm{a}$ & $0.87 \pm 0.18 \mathrm{~b}$ \\
\hline
\end{tabular}

* Values are expressed as mean \pm SD of four determinations. Different letters (a, b, c, d) indicate significant difference $(P<0.05)$.

(Table 1). Our results support the hypothesis that molecular structure does not control long-term stabilization of organic matter in mineral soils (Schmidt et al., 2011 and references therein). The persistence of SOM is actually dependent on complex interactions between organic matter and its environment such as compound chemistry, climate, water availability, soil $\mathrm{pH}$ and soil microbial community (Schmidt et al., 2011; Thevenot et al., 2010).

Another hypothesis for the low concentration of aliphatic lipids and lignin in DG is physical removal of fine fractions. It has been reported that lignin and aliphatic components in soils are enriched in fine particles (Quenea et al., 2004; Thevenot et al., 2010). In the arid and semiarid region of Inner Mongolia, strong wind erosion can disproportionately remove clay contents of grasslands (e.g., $1.7 \%$ in DG versus $4.6 \%$ in NG; Table 1), and thereby reduce proportions of aliphatic and lignin biomarkers in SOM. The investigation for the different size fractions of soils is greatly needed in future study in order to ascertain which mechanism is more important for observed change patterns of different biomarkers.

With land use changes such as cultivation activities, planting indigenous grasses, banning grazing and groundwater supply, the abundance of $\omega-\mathrm{OH}$ alkanoic acids and $\alpha-\mathrm{OH}$ alkanoic acids in soils increased in RG and GG compared to NG, whereas the abundance of lignins and free lipids significantly decreased (Fig. 3). In the grassland ecosystems, long-chain $\omega$-OH alkanoic acids are predominantly derived from suberin of roots (Kolattukudy and Espelie, 1989; Otto and Simpson, 2006b), whereas $\alpha-\mathrm{OH}$ alkanoic acids are characteristic of both cutin of leaf waxes and suberin of roots (Deleeuw et al., 1995; Otto and Simpson, 2006a). In order to estimate response of biomarkers to land use changes, we defined an enrichment factor $\left(E_{\mathrm{C}}\right)$ which is a ratio of the biomarker concentration in the disturbed grasslands over the native grasslands. The mean values of $E_{\mathrm{C}}$ were $1.69(\mathrm{GG})$ and $1.66(\mathrm{RG})$ for $\omega-\mathrm{OH}$ alkanoic acids, $1.24(\mathrm{GG})$ and 1.18 (RG) for $\alpha-\mathrm{OH}$ alkanoic acids, but only $0.64(\mathrm{GG})$ and 0.87 (RG) for lignin-phenols (Table 3), suggesting that more 
suberin-derived carbon have been sequestered in soils. In order to better understand this SOM change, the next step will be the quantification of biomass inputs in Inner Mongolian grasslands with different degrees of human disturbance.

\section{Conclusions}

By analyzing bulk and biomarker characteristics of grassland soils in Inner Mongolia (China), we confirm that land use changes alter soil organic carbon not only in quantity but also in molecular compositions. Over 10 years of overgrazing has caused about a $50 \%$ reduction of soil organic carbon and nitrogen, whereas the groundwater supply and potato cultivation-restoration activities have been beneficial for the accumulation of soil organic carbon and nitrogen. With land use changes, the root-derived aliphatic carbon (e.g., suberin) are preferentially preserved in soils compared to aboveground-derived carbon. This finding is important for the prediction of global carbon cycling under climate and land use changes, since root-derived carbon (particularly aliphatic suberin) has longer residence time than aboveground carbon (Rasse et al., 2005) and other type of organic carbon (e.g., lignin) in soils (Feng and Simpson, 2007; Lorenz et al., 2007). A future study will be the quantification of biomass inputs from different vegetation to better understand soil organic matter dynamic under the different land uses in Inner Mongolia. 


\section{Appendix A}

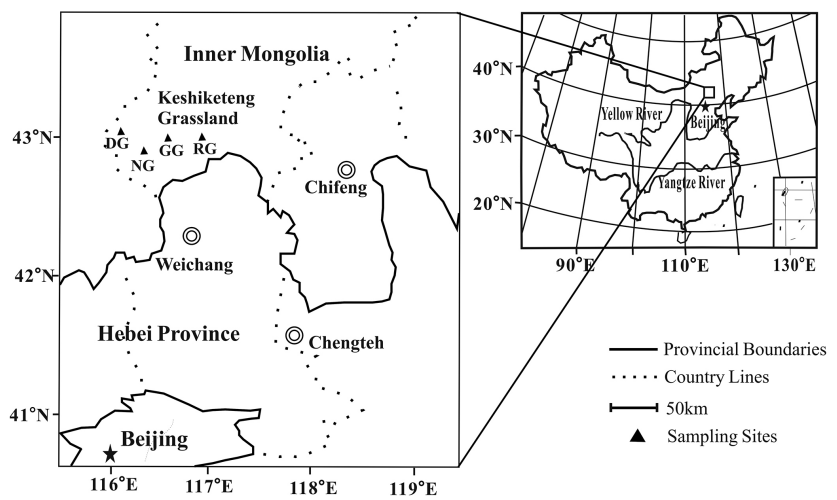

Figure A1. Map of the sampling sites in Inner Mongolia, northern China.

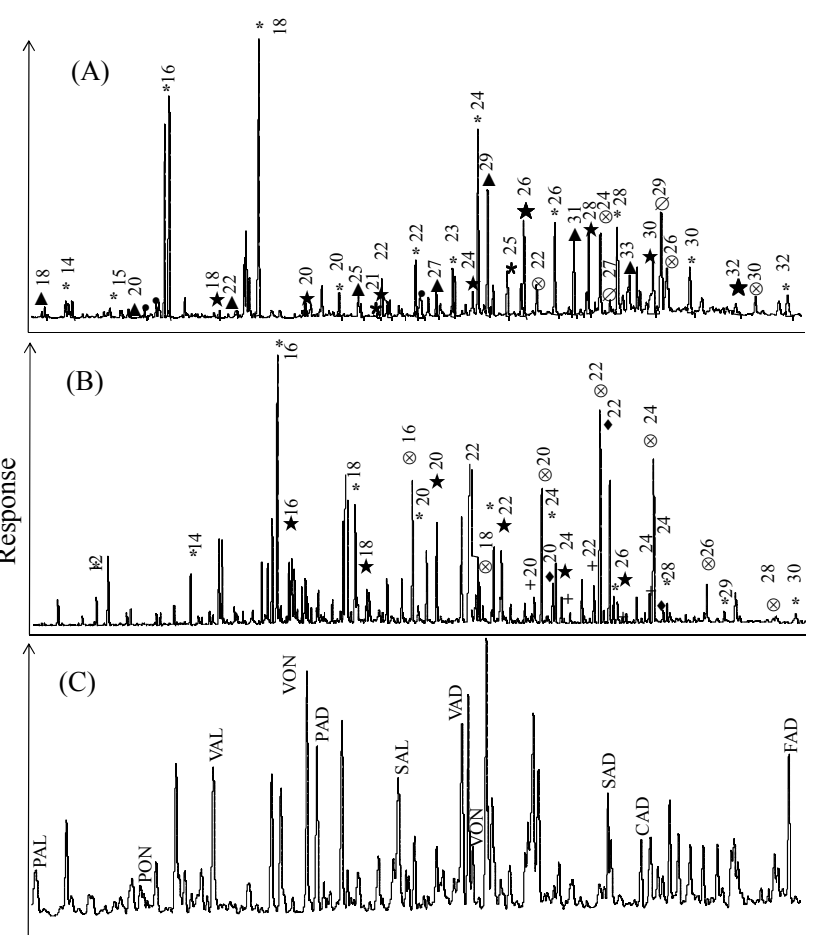

Retention time

Figure A2. Gas chromatograms of (a) solvent extractable fraction; (b) base hydrolysable fraction and (c) $\mathrm{CuO}$ oxidation products of grassland soils in Inner Mongolia, northern China: $n$-alkanes; $\star: n$ alkanols; *: $n$-fatty acids (FA); $\otimes: \omega$-OH-FA; Ø: sterols; •: sugars; $+: n$-diacids (DA); $\diamond: \alpha$-OH-FA. Numbers refer to total carbon numbers in individual biomarkers. Pal: $p$-Hydroxybenzaldehyde; Pon: $p$-Hydroxyacetophenone; Pad: $p$-Hydroxybenzoic acid; Val: vanillin; Sal: syringaldehyde; Von: acetovanillone; Son: acetosyringone; Vad : vanillic acid; Sad: syringic acid; Cad: $p$-coumaric acid; Fad: ferulic acid. 
Acknowledgements. This study was financially supported by the National Basic Research Program of China (2014CB954001) and the National Science Foundation of China (41476062, 41176164). We thank Chengyang Zheng and Hongyan Liu for assistance in sampling.

Edited by: R. Bol

\section{References}

Amelung, W., Brodowski, S., Sandhage-Hofmann, A., and Bol, R.: Combining biomarker with stable isotope analyses for assessing the transformation and turnover of soil organic matter, Adv. Agron., 100, 155-250, 2008.

Anderson, D., Saggar, S., Bettany, J., and Stewart, J.: Particle size fractions and their use in studies of soil organic matter: I. The nature and distribution of forms of carbon, nitrogen, and sulfur, Soil Sci. Soc. Am. J., 45, 767-772, 1981.

Baldock, J. A. and Skjemstad, J. O.: Role of the soil matrix and minerals in protecting natural organic materials against biological attack, Org. Geochem., 31, 697-710, 2000.

Bateman, A. S., Kelly, S. D., and Jickells, T. D.: Nitrogen isotope relationships between crops and fertilizer: implications for using nitrogen isotope analysis as an indicator of agricultural regime, J. Agr. Food Chem., 53, 5760-5765, 2005.

Cui, X., Wang, Y., Niu, H., Wu, J., Wang, S., Schnug, E., Rogasik, J., Fleckenstein, J., and Tang, Y.: Effect of long-term grazing on soil organic carbon content in semiarid steppes in Inner Mongolia, Ecol. Res., 20, 519-527, 2005.

Deleeuw, J. W., Rijpstra, W. I. C., and Nienhuis, P. H.: Free and bound fatty-acids and hydroxy fatty-acids in the living and decomposing eelgrass zostera-marina L., Org. Geochem., 23, 721728, 1995.

Dignac, M. F., Bahri, H., Rumpel, C., Rasse, D. P., Bardoux, G., Balesdent, J., Girardin, C., Chenu, C., and Mariotti, A.: Carbon13 natural abundance as a tool to study the dynamics of lignin monomers in soil: an appraisal at the Closeaux experimental field (France), Geoderma, 128, 3-17, 2005.

Farquhar, G. D., Ehleringer, J. R., and Hubick, K. T.: Carbon isotope discrimination and photosynthesis, Annu. Rev. Plant Biol., 40, 503-537, 1989.

Feng, X.: A theoretical analysis of carbon isotope evolution of decomposing plant litters and soil organic matter, Global Biogeochem. Cy., 16, 1119, doi:10.1029/2002GB001867, 2002.

Feng, X., Simpson, A. J., Wilson, K. P., Dudley Williams, D., and Simpson, M. J.: Increased cuticular carbon sequestration and lignin oxidation in response to soil warming, Nat. Geosci., 1, 836-839, 2008.

Feng, X. J. and Simpson, M. J.: The distribution and degradation of biomarkers in Alberta grassland soil profiles, Org. Geochem., 38, 1558-1570, 2007.

Feng, X. M. and Zhao, Y. S.: Grazing intensity monitoring in Northern China steppe: integrating CENTURY model and MODIS data, Ecol. Indic., 11, 175-182, 2011.

Gleixner, G., Poirier, N., Bol, R., and Balesdent, J.: Molecular dynamics of organic matter in a cultivated soil, Org. Geochem., 33, 357-366, 2002.
Guo, L., Wang, M., and Gifford, R.: The change of soil carbon stocks and fine root dynamics after land use change from a native pasture to a pine plantation, Plant Soil, 299, 251-262, 2007.

He, N., Yu, Q., Wu, L., Wang, Y., and Han, X.: Carbon and nitrogen store and storage potential as affected by land-use in a Leymus chinensis grassland of northern China, Soil Biol. Biochem., 40, 2952-2959, 2008.

Hedges, J. I. and Mann, D. C.: The characterization of plant tissues by their lignin oxidation products, Geochim. Cosmochim. Ac., 43, 1803-1807, 1979.

Hedges, J. I., Blanchette, R. A., Weliky, K., and Devol, A. H.: Effects of fungal degradation on the $\mathrm{CuO}$ oxidation products of lignin: a controlled laboratory study, Geochim. Cosmochim. Ac., 52, 2717-2726, 1988.

Islam, K. R. and Weil, R. R.: Land use effects on soil quality in a tropical forest ecosystem of Bangladesh, Agr. Ecosyst. Environ., 79, 9-16, 2000.

Janzen, H. H.: Carbon cycling in earth systems - a soil science perspective, Agr. Ecosyst. Environ., 104, 399-417, 2004.

Jiang, G., Han, X., and Wu, J.: Restoration and management of the Inner Mongolia grassland require a sustainable strategy, Ambio, 35, 269-270, 2006.

Kögel-Knabner, I.: Analytical approaches for characterizing soil organic matter, Org. Geochem., 31, 609-625, 2000.

Kögel-Knabner, I.: The macromolecular organic composition of plant and microbial residues as inputs to soil organic matter, Soil Biol. Biochem., 34, 139-162, 2002.

Kaiser, M., Wirth, S., Ellerbrock, R. H., and Sommer, M.: Microbial respiration activities related to sequentially separated, particulate and water-soluble organic matter fractions from arable and forest topsoils, Soil Biol. Biochem., 42, 418-428, 2010.

Kohl, D. H., Shearer, G. B., and Commoner, B.: Variation of ${ }^{15} \mathrm{~N}$ in corn and soil following application of fertilizer nitrogen, Soil Sci. Soc. Am. J., 37, 888-892, 1973.

Kolattukudy, P. E. and Espelie, K. E.: Chemistry, biochemistry, and function of suberin and associated waxes, in: Natural Products of Woody Plants, edited by: Rowe, J., Springer Series in Wood Science, Springer, Berlin, Heidelberg, 304-367, 1989.

Leifeld, J. and Kögel-Knabner, I.: Soil organic matter fractions as early indicators for carbon stock changes under different landuse?, Geoderma, 124, 143-155, 2005.

Lorenz, K., Lal, R., Preston, C. M., and Nierop, K. G.: Strengthening the soil organic carbon pool by increasing contributions from recalcitrant aliphatic bio (macro) molecules, Geoderma, 142, 1$10,2007$.

Natelhoffer, K. J. and Fry, B.: Controls on natural nitrogen-15 and carbon-13 abundances in forest soil organic matter, Soil Sci. Soc. Am. J., 52, 1633-1640, 1988.

National Statistics Bureau of China: China Statistics Yearbook, Beijing, 6 pp., 2002.

Nichols, J. D.: Relation of organic carbon to soil properties and climate in the southern Great Plains, Soil Sci. Soc. Am. J., 48, 1382-1384, 1984.

Nierop, K. G. J., Naafs, D. F. W., and Verstraten, J. M.: Occurrence and distribution of ester-bound lipids in Dutch coastal dune soils along a pH gradient, Org. Geochem., 34, 719-729, 2003.

O'Leary, M. H.: Carbon isotope fractionation in plants, Phytochemistry, 20, 553-567, 1981. 
Otto, A. and Simpson, M. J.: Evaluation of $\mathrm{CuO}$ oxidation parameters for determining the source and stage of lignin degradation in soil, Biogeochemistry, 80, 121-142, 2006a.

Otto, A. and Simpson, M. J.: Sources and composition of hydrolysable aliphatic lipids and phenols in soils from western Canada, Org. Geochem., 37, 385-407, 2006b.

Otto, A., Shunthirasingham, C., and Simpson, M. J.: A comparison of plant and microbial biomarkers in grassland soils from the Prairie Ecozone of Canada, Org. Geochem., 36, 425-448, 2005.

Pisani, O., Hills, K. M., Courtier-Murias, D., Simpson, A. J., Mellor, N. J., Paul, E. A., Morris, S. J., and Simpson, M. J.: Molecular level analysis of long term vegetative shifts and relationships to soil organic matter composition, Org. Geochem., 62, 7-16, 2013.

Quenea, K., Derenne, S., Largeau, C., Rumpel, C., and Mariotti, A.: Variation in lipid relative abundance and composition among different particle size fractions of a forest soil, Org. Geochem., 35, 1355-1370, 2004.

Rasse, D., Rumpel, C., and Dignac, M.-F.: Is soil carbon mostly root carbon? Mechanisms for a specific stabilisation, Plant Soil, 269, 341-356, 2005.

Schlesinger, W. H. and Andrews, J. A.: Soil respiration and the global carbon cycle, Biogeochemistry, 48, 7-20, 2000.

Schmidt, M. W. I., Torn, M. S., Abiven, S., Dittmar, T., Guggenberger, G., Janssens, I. A., Kleber, M., Kogel-Knabner, I., Lehmann, J., Manning, D. A. C., Nannipieri, P., Rasse, D. P., Weiner, S., and Trumbore, S. E.: Persistence of soil organic matter as an ecosystem property, Nature, 478, 49-56, 2011.

Simoneit, B. R.: A review of current applications of mass spectrometry for biomarker/molecular tracer elucidations, Mass Spectrom. Rev., 24, 719-765, 2005.

Su, Y.-Z., Li, Y.-L., Cui, J.-Y., and Zhao, W.-Z.: Influences of continuous grazing and livestock exclusion on soil properties in a degraded sandy grassland, Inner Mongolia, northern China, Catena, 59, 267-278, 2005.
Sun, D. Y., Tan, W. B., Pei, Y. D., Zhou, L. P., Wang, H., Yang, H., and $\mathrm{Xu}$, Y. P.: Late Quaternary environmental change of Yellow River Basin: an organic geochemical record in Bohai Sea (North China), Org. Geochem., 42, 575-585, 2011.

Tan, W. B., Zhou, L. P., and Liu, K. X.: Soil aggregate fractionbased C-14 analysis and its application in the study of soil organic carbon turnover under forests of different ages, Chinese Sci. Bull., 58, 1936-1947, 2013.

Thevenot, M., Dignac, M.-F., and Rumpel, C.: Fate of lignins in soils: a review, Soil Biol. Biochem., 42, 1200-1211, 2010.

Wang, G., Feng, X., Han, J., Zhou, L., Tan, W., and Su, F.: Paleovegetation reconstruction using $\delta^{13} \mathrm{C}$ of Soil Organic Matter, Biogeosciences, 5, 1325-1337, doi:10.5194/bg-5-1325-2008, 2008.

Wang, Z.-P., Han, X.-G., Chang, S. X., Wang, B., Yu, Q., Hou, L.Y., and Li, L.-H.: Soil organic and inorganic carbon contents under various land uses across a transect of continental steppes in Inner Mongolia, Catena, 109, 110-117, 2013.

Watson, R. T.: Land Use, Land-Use Change, and Forestry: a Special Report of the Intergovernmental Panel on Climate Change, Cambridge University Press, 2000.

Wiesenberg, G. L. B., Schmidt, M. W. I., and Schwark, L.: Plant and soil lipid modifications under elevated atmospheric $\mathrm{CO}_{2}$ conditions: I. Lipid distribution patterns, Org. Geochem., 39, 91-102, 2008.

Wu, W., Ruan, J., Ding, S., Zhao, L., Xu, Y., Yang, H., Ding, W., and Pei, Y.: Source and distribution of glycerol dialkyl glycerol tetraethers along lower Yellow River-estuary-coast transect, Mar. Chem., 158, 17-26, 2014.

Xiao, X., Ojima, D., Parton, W., Chen, Z., and Chen, D.: Sensitivity of Inner Mongolia grasslands to climate change, J. Biogeogr., 22 643-648, 1995.

Zhao, Y., Peth, S., Krümmelbein, J., Horn, R., Wang, Z., Steffens, M., Hoffmann, C., and Peng, X.: Spatial variability of soil properties affected by grazing intensity in Inner Mongolia grassland, Ecol. Model., 205, 241-254, 2007.

Zhou, Z., Sun, O., Huang, J., Li, L., Liu, P., and Han, X.: Soil carbon and nitrogen stores and storage potential as affected by land-use in an agro-pastoral ecotone of northern China, Biogeochemistry, 82, 127-138, 2007. 